\title{
Failure of Glucagon to Stimulate Ketone Body Production During Acute Insulin Deficiency or Insulin Replacement in Man
}

\author{
G. E. Sonnenberg ${ }^{1}$, W. Stauffacher ${ }^{2}$, and U. Keller ${ }^{1,2}$ \\ Departments of ${ }^{1}$ Research and ${ }^{2}$ Medicine, University Hospital, Basle, Switzerland
}

\begin{abstract}
Summary. To assess the role of glucagon and insulin in the acute regulation of ketone body kinetics in man, somatostatin was administered with various combinations of these hormones by replacement infusions in groups of six to seven normal subjects. Somatostatin-induced insulin and glucagon deficiency produced a threefold increase in total ketone body concentrations within $2 \mathrm{~h}$. This increase was the combined result of enhanced production (71\%), and decreased metabolic clearance (32\%), as determined by ${ }^{14} \mathrm{C}$-acetoacetate infusions. An associated elevation of non-esterified fatty acids $(66 \%)$ and glycerol levels occurred. Glucagon replacement $\left(2 \mathrm{ng} \cdot \mathrm{kg}^{-1}\right.$. $\min ^{-1}$ ) during insulin deficiency failed to enhance ketogenesis or lipolysis but lowered the $\beta$-hydroxybutyrate/acetoacetate concentration ratios. Hyperglycaemia, observed during glucagon administration and insulin deficiency, did not di-
\end{abstract}

minish ketone body production or lipolysis. In contrast, insulin replacement $\left(150 \mu \mathrm{U} \cdot \mathrm{kg}^{-1} \cdot \mathrm{min}^{-1}\right)$ diminished lipolysis, lowered ketone production, and elevated the metabolic clearance rate of ketone bodies. Glucagon infusions ( 2 and $4 \mathrm{ng}$. $\mathrm{kg}^{-1} \cdot \min ^{-1}$ ) during somatostatin and insulin replacement did not accelerate ketone body production or raise non-esterified fatty acid levels, but produced a dose-dependent elevation of blood glucose levels. The results suggest that glucagon is not an important ketogenic hormone under the conditions studied.

Key words: Ketone body turnover, ketogenesis, acetone, lipolysis, insulin, diabetes, glucagon, somatostatin, non-esterified fatty acids, glycerol, glucose.
Ketone body concentrations may reach markedly elevated levels during various physiological and pathological conditions, such as fasting and diabetic ketoacidosis [1]. Controlling factors are involved which enhance or inhibit the accumulation of ketone bodies in the blood. It has been recognized recently in a study performed in rats, that ketogenesis is under the bihormonal control of insulin and glucagon [2]. However, the relative roles of these two hormones in regulating ketone body production or utilization has not been defined in man. While it is generally agreed that insulin deficiency enhances ketogenesis, controversial results have been obtained regarding the ketogenic capacity of glucagon. An increase. in ketone body concentrations was observed after glucagon administration to insulin-withdrawn diabetic patients [3-5]. In contrast, glucagon failed to stimulate ketogenesis in normal man $[3,6]$, probably due to counterregulatory insulin release following glucagon administration which suppressed the potential ketogenic effects of glucagon.

The present studies were performed to assess the effect of acute alterations in insulin and glucagon levels on concentrations and kinetics of ketone bodies. Production and utilization of total ketone bodies were determined using primed continuous infusions of $3-{ }^{14} \mathrm{C}$ acetoacetate. Administration of somatostatin provided an acute deficiency of insulin and glucagon; it also prevented counter-regulatory release of either hormone by the other, during various replacement infusions of insulin and glucagon.

\section{Subjects and Methods}

\section{Subjects}

Thirty-five healthy subjects ( 13 males and 22 females) aged between 43 and 66 years participated in the study. Each subject's weight was within $10 \%$ of his ideal body weight (based upon 1959 Metropolitan Life Insurance Tables). The oral glucose tolerance test, haematocrit, serum electrolytes, urea and liver enzymes were within normal limits before the study. The investigation was approved by the Local Ethical Committee, and written informed consent was obtained from all participants. 


\section{Experimental Procedures}

The subjects reported to the laboratory after a 13-h overnight fast, following consumption of a light meal at $19.00 \mathrm{~h}$ on the previous day. A Venflo catheter (inner diameter: $1.2 \mathrm{~mm}$ ) was inserted into an antecubital vein for infusion. The hand of the contralateral arm was placed in a warming chamber at $60^{\circ} \mathrm{C}$, and arterialized venous blood was sampled from a dorsal hand vein by a Butterfly needle (inner diameter: $0.8 \mathrm{~mm}$ ) [7]. A primed constant infusion of sodium $3{ }^{14} \mathrm{C}$-acetoacetate $(0.56-0.72 \mu \mathrm{Ci} / \mathrm{min})$ was administered throughout the study. Blood samples were obtained during $14 \mathrm{~min}$ at 2 min intervals following primer injection $(20 \mu \mathrm{C}$ ) for determination of the pool size of ketone bodies, and after $40 \mathrm{~min}$ of tracer equilibration, at 10 and $15 \mathrm{~min}$ intervals during $165 \mathrm{~min}$.

Infusion protocols: (1) saline $(0.154 \mathrm{~mol} / \mathrm{l})$; (2) somatostatin $(6.5$ $\left.\mu \mathrm{g} \cdot \mathrm{kg}^{-1} \cdot \mathrm{h}^{-1}\right)$, either alone or in combination with: (3) glucagon $\left(2 \mathrm{ng} \cdot \mathrm{kg}^{-1} \cdot \mathrm{min}^{-1}\right)$; (4) glucose $\left(20 \mathrm{~g} / 100 \mathrm{ml} \mathrm{H} \mathrm{H}_{2} \mathrm{O}\right)$ to produce comparable hyperglycaemia to that observed during glucagon infusions; (5) insulin replacement $\left(150 \mu \mathrm{U} \cdot \mathrm{kg}^{-1} \cdot \mathrm{min}^{-1}\right) ;(6)$ insulin replacement and glucagon $\left(2 \mathrm{ng} \cdot \mathrm{kg}^{-1} \cdot \mathrm{min}^{-1}\right) ;(7)$ insulin replacement and glucagon $\left(4 \mathrm{ng} \cdot \mathrm{kg}^{-1} \cdot \min ^{-1}\right)$.

\section{Preparation of Infusates}

$3{ }^{14} \mathrm{C}$-ethylacetoacetate $(160 \mu \mathrm{Ci}$, sp. act. $9.2 \mathrm{Ci} / \mathrm{mol}$, Amersham International, Bucks., UK) was added to freshly redistilled carrier ethylacetoacetate $(0.5 \mathrm{mmol})$. After hydrolysis with $\mathrm{NaOH}(10 \%$ excess) and incubation for $60 \mathrm{~min}$ at $40^{\circ} \mathrm{C}$, the solution was evaporated to approximately half of its initial volume to remove ethanol, acetone and water [8]. The purity of the tracer [9] was $86 \pm 1 \%$ (range $76 \%-99 \%$ ). The infusates were sterilized by passing through a Millipore filter $(0.22 \mu \mathrm{m})$ and stored in sterile flasks at $-60^{\circ} \mathrm{C}$ until use (within 8 weeks). Cyclic somatostatin was purchased from Serono, Freiburg, FRG; insulin (Actrapid) and glucagon were obtained from Novo, Copenhagen, Denmark. Somatostatin, insulin and glucagon were dissolved in saline $(0.154 \mathrm{~mol} / \mathrm{l})$ containing human albumin $(0.5 \mathrm{~g} / 100 \mathrm{ml})$. All infusates were delivered using Harvard pumps. During the hyperglycaemia study, glucose $\left(20 \mathrm{~g} / 100 \mathrm{ml} \mathrm{H}_{2} \mathrm{O}\right)$ was administered at rates which were periodically adjusted according to instantaneously measured blood glucose levels.

\section{Analytical Procedures}

The blood samples were drawn with heparinized syringes and collected in tubes containing $5 \mathrm{mg} / \mathrm{ml}$ EDTA. Aliquots $(4.5 \mathrm{ml})$ were immediately deproteinized by adding equal volumes of chilled $\mathrm{HClO}_{4}$ $\left(30 \mathrm{~g} / 100 \mathrm{ml} \mathrm{H}_{2} \mathrm{O}\right)$ and neutralized with $\mathrm{KOH}\left(20 \mathrm{~g} / 100 \mathrm{ml} \mathrm{H} \mathrm{H}_{2} \mathrm{O}\right)$. Blood concentrations of acetoacetate [10] and $\beta$-hydroxybutyrate [11], glycerol [12], and glucose [13] were measured using a microfluorimetric adaption of enzymatic methods. In the hyperglycaemia studies (protocol 4), blood glucose was determined instantly by a Yellow Spring glucose analyzer (Yellow Springs Instrument Co, Yellow Springs, Ohio, USA). Blood acetone was determined using head space analysis and gas chromatography [14]. Acetoacetate and acetone were assayed within $6 \mathrm{~h}$, during which period both were shown to be stable. ${ }^{14} \mathrm{C}$-ketone bodies were determined as described previously [9]. Recoveries determined in all studies were $87 \pm 1 \%$ for ${ }^{14} \mathrm{C}$ acetoacetate, and $84 \pm 2 \%$ for ${ }^{14} \mathrm{C}-\beta$-hydroxybutyrate. The sp. act. of acetoacetate and of total ketone bodies included acetone values. Plasma non-esterified fatty acids (NEFA) were measured by a radiochemical method [15], plasma immunoreactive insulin using Sephadexbound antibodies [16], and immunoreactive glucagon in plasma containing Trasylol $(500 \mathrm{IU} / \mathrm{ml})$ using the $30 \mathrm{~K}$ antibody obtained from Dr. Unger, Dallas, Texas [17].

Total ketone body kinetics were calculated using a single pool model as originally described for glucose [18] and as recently validated for ketone bodies [19]. The pool sizes of total ketone bodies were determined in each subject as described previously [19]; a pool fraction of total ketone bodies of 1.0 was employed. Total ketone body production was obtained by using the combined sp. act. of individual ketone bodies in the calculation. The metabolic clearance rate was calculated by dividing the rate of utilization by the concentration, as the latter has been used previously as an index of efficiency of utilization of ketone bodies [20]. In the calculation of the metabolic clearance rate of ketone bodies, urinary losses of ${ }^{14} \mathrm{C}$-ketone bodies were neglected, since $<1 \%$ of the infused radioactivity was shown to be lost in the urine during the experimental period. Calculations were performed using a Hewlett-Packard 9815 desk top computer. Results are presented as mean \pm SEM. Student's paired t-test was used for the comparison of two experimental periods in the same subject. The unpaired t-test was employed for the assessment of statistical significance between different protocols.

\section{Results}

\section{Effect of Saline Infusion on Ketone Body Kinetics (Table 1)}

The production rates of total ketone bodies rose slightly during the study from $6.3 \pm 1.3 \mu \mathrm{mol} \cdot \mathrm{kg}^{-1} \cdot \mathrm{min}^{-1}$ during the control period to $8.7 \pm 1.6 \mu \mathrm{mol} \cdot \mathrm{kg}^{-1}$. $\min ^{-1}$ at $150 \min (p<0.02)$. The utilization rates of total ketone bodies followed the production rates closely; consequently there was a small but significant increase in total ketone body concentrations $(47 \%, p<0.01)$. There was also a significant increase in $\beta$-hydroxybutyrate concentrations $(81 \%, p<0.005)$. Blood acetoacetate, acetone, metabolic clearance rate of ketone bodies, plasma insulin and glucagon did not change significantly.

\section{Effect of Somatostatin-Induced Insulin and Glucagon Deficiency on Ketone Body Kinetics (Fig. 1)}

Somatostatin infusion (protocol .2) resulted in a decrease of insulin at $150 \mathrm{~min}$ from $5.6 \pm 0.6$ to $1.7 \pm$ $0.4 \mathrm{mU} / 1(p<0.01)$, and of glucagon from $132 \pm 14$ to $89 \pm 16 \mathrm{pg} / \mathrm{ml}(p<0.001)$. While plasma insulin was suppressed to the detection limit of our assay, glucagon concentrations were still clearly measurable. The total ketone body concentrations increased almost threefold, from $364 \pm 120$ to $1081 \pm 231 \mu \mathrm{mol} / 1(p<0.01)$. This increase was entirely due to the elevation of $\beta$-hydroxybutyrate which rose from $210 \pm 68$ to $851 \pm$ $180 \mu \mathrm{mol} / 1(p<0.005)$. Blood acetone levels increased from $29 \pm 11$ to $50 \pm 12 \mu \mathrm{mol} / 1$ ( $\mathrm{p}<0.005)$, whereas acetoacetate concentrations remained unchanged and the $\beta$-hydroxybutyrate/acetoacetate concentration ratios rose from $2.0 \pm 0.05$ to $4.5 \pm 0.4(p<0.001)$. The increase in total ketone body concentrations during the 120 min of hormonal perturbation was due in part to increased ketone body production, which rose during somatostatin infusion from $7.7 \pm 2.7$ to $13.2 \pm 2.2$ $\mu \mathrm{mol} \cdot \mathrm{kg}^{-1} \cdot \min ^{-1}(p<0.001)$. Total ketone body utilization followed the production rates closely, but with a slight delay. The metabolic clearance rate of total ketone bodies declined significantly by $32 \%(p<0.005)$ which augmented the ketonaemic effect of the in- 
Table 1. Effect of glucagon on ketone body kinetics at $150 \mathrm{~min}$ during somatostatin-induced insulin deficiency and during insulin replacement

\begin{tabular}{|c|c|c|c|c|c|c|c|}
\hline Protocol number & $\begin{array}{l}\text { Number } \\
\text { of } \\
\text { patients }\end{array}$ & \multicolumn{2}{|c|}{$\begin{array}{l}\text { Total ketone body } \\
\text { production } \\
\left(\mu \mathrm{mol} \cdot \mathrm{kg}^{-1} \cdot \min ^{-1}\right)\end{array}$} & \multicolumn{2}{|c|}{$\begin{array}{l}\text { Metabolic clearance rate } \\
\text { of ketone bodies } \\
\left(\mathrm{ml} \cdot \mathrm{kg}^{-1} \cdot \min ^{-1}\right)\end{array}$} & \multicolumn{2}{|c|}{$\begin{array}{l}\text { Total ketone body } \\
\text { concentration } \\
(\mu \mathrm{mol} / 1)\end{array}$} \\
\hline 1) Saline & 6 & $8.7 \pm 1.6$ & $2.3 \pm 0.7$ & $16.2 \pm 1.8$ & $-0.2 \pm 1.3$ & $630 \pm 120$ & $153 \pm 43$ \\
\hline $\begin{array}{l}\text { 3) SS + glucagon } \\
\left(2 \mathrm{ng} \cdot \mathrm{kg}^{-1} \cdot \min ^{-1}\right)\end{array}$ & 7 & $14.0 \pm 1.9$ & $6.3 \pm 1.3^{c}$ & $13.5 \pm 1.3$ & $-4.8 \pm 1.2^{\mathrm{a}}$ & $1020 \pm 119$ & $674 \pm 95^{c}$ \\
\hline 4) SS + hyperglycaemia & 6 & $12.6 \pm 1.2$ & $5.1 \pm 1.0^{\mathrm{c}}$ & $10.6 \pm 1.1$ & $-2.6 \pm 1.3$ & $1145 \pm 103$ & $605 \pm 71^{c}$ \\
\hline $\begin{array}{l}\text { 5) } \mathrm{SS}+\text { insulin } \\
\left(150 \mu \mathrm{U} \cdot \mathrm{kg}^{-1} \cdot \mathrm{min}^{-1}\right)\end{array}$ & 6 & $6.9 \pm 1.3^{d}$ & $1.2 \pm 1.4^{\mathrm{d}}$ & $23.7 \pm 3.3^{\mathrm{d}}$ & $6.9 \pm 2.4^{\mathrm{c}, \mathrm{d}}$ & $343 \pm 118^{d}$ & $-13 \pm 95^{d}$ \\
\hline
\end{tabular}

Results expressed as mean $\pm \mathrm{SEM} ;{ }^{a} p<0.025,{ }^{b} p<0.01,{ }^{c} p<0.001$ versus saline, ${ }^{\mathrm{d}} p<0.01$ versus somatostatin

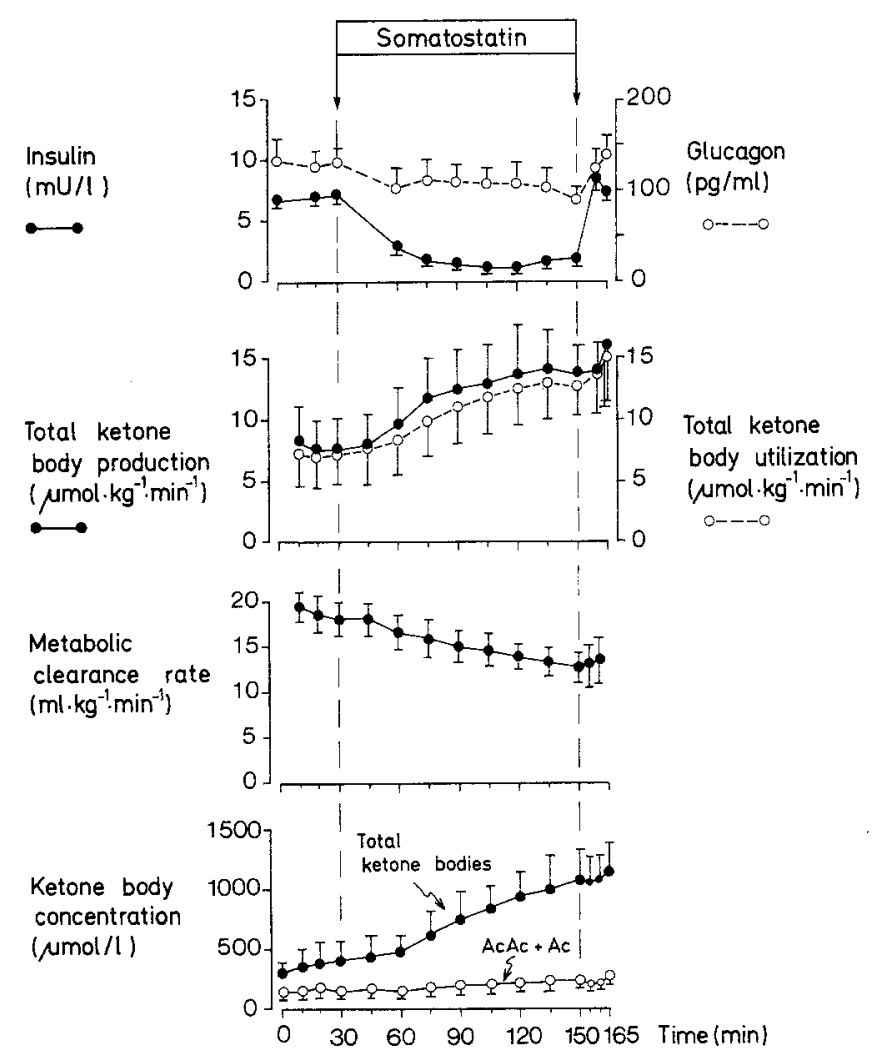

Fig. 1. Effect of somatostatin-induced insulin and glucagon deficiency on total ketone body kinetics in six normal subjects fasted overnight. After $75 \mathrm{~min}$, the increase in ketone body production, utilization and concentration, and the decrease of the metabolic clearance rate from the control period were significant $(p<0.01)$. Results expressed as mean \pm SEM

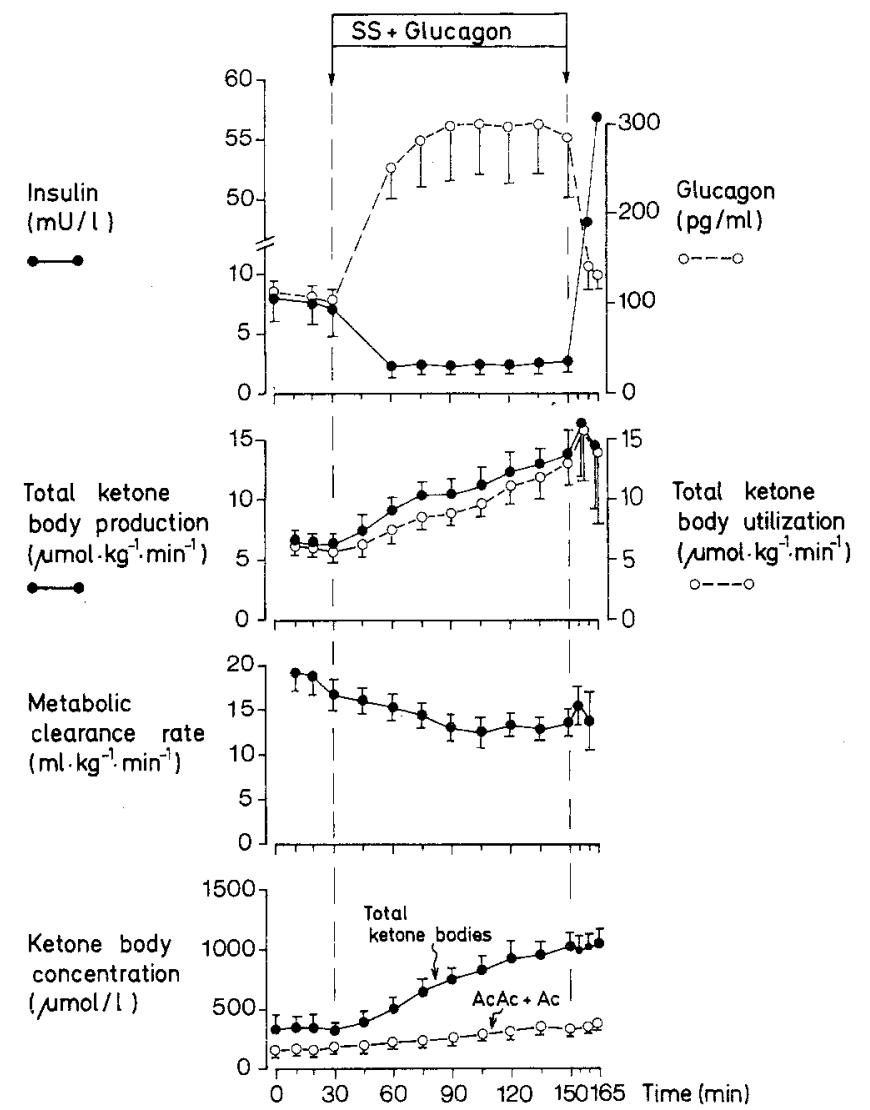

Fig. 2. Effect of somatostatin (SS) and glucagon replacement at $2 \mathrm{ng}$. $\mathrm{kg}^{-1} \cdot \min ^{-1}$ on insulin, glucagon and total ketone body kinetics in seven subjects. After 60 min, ketone body production, utilization, metabolic clearance rate and concentrations were significantly different from control values $(p<0.01)$. Results expressed as mean \pm SEM 


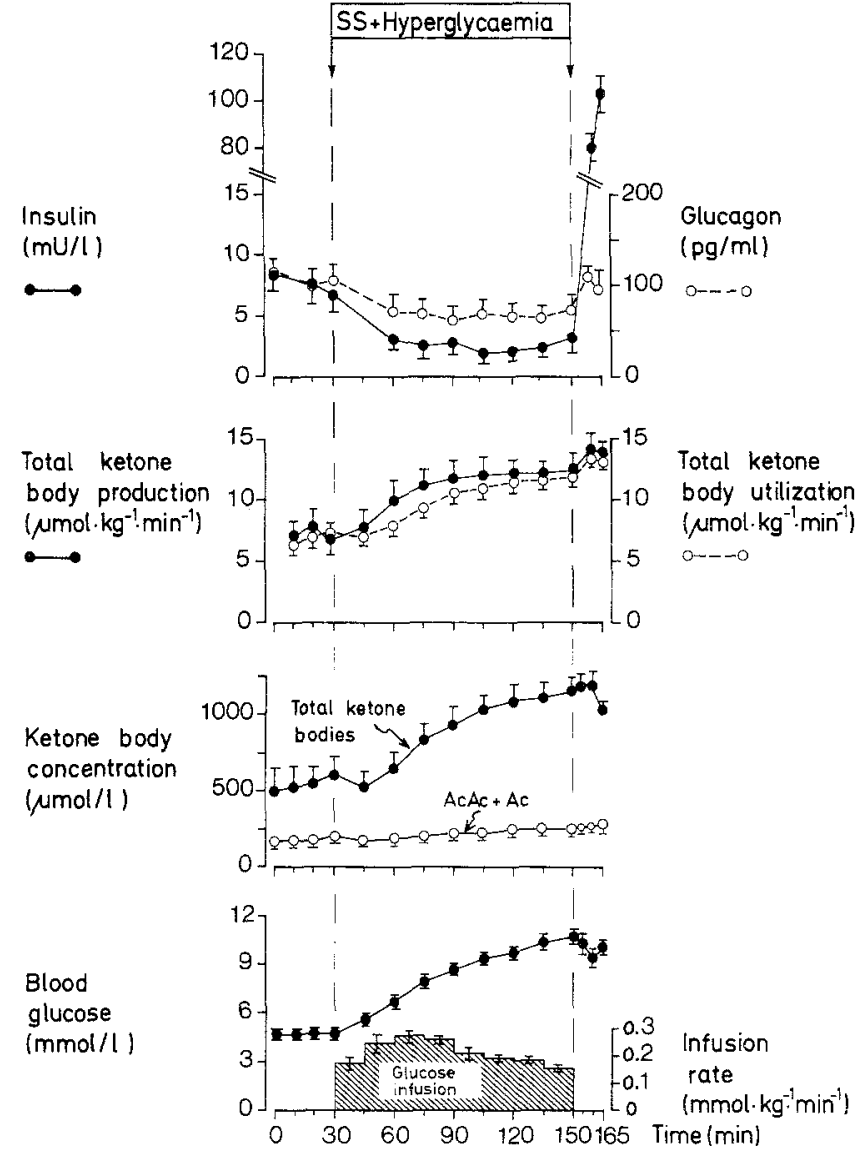

Fig. 3. Insulin, glucagon and ketone body kinetics during infusion of somatostatin (SS) and glucose in six subjects. Glucose $(200 \mathrm{~g} / \mathrm{l})$ was infused at variable rates (bottom panel) to mimic the hyperglycaemia of protocol 3 (Fig. 2). The rates were adjusted in 15 min intervals according to instant blood glucose measurements. Results expressed as mean \pm SEM

creased production. The elevation of ketone body production and the decrease of the metabolic clearance rate were significantly greater than during saline infusion $(p<0.01$, Table 1$)$.

\section{Effect of Somatostatin-Induced Insulin Deficiency} and Glucagon Replacement $\left(2 \mathrm{ng} \cdot \mathrm{kg}^{-1} \cdot \mathrm{min}^{-1}\right)$ on Ketone Body Kinetics (Fig. 2)

Infusion of somatostatin and glucagon (protocol 3) resulted in insulin deficiency and mild hyperglucagonaemia of $303 \pm 59 \mathrm{pg} / \mathrm{ml}$. Total ketone body concentrations increased similarly as during somatostatin infusion alone, rising from $347 \pm 63$ to $1020 \pm 119 \mu \mathrm{mol} / 1$ at $150 \mathrm{~min}(p<0.01)$. This increase was the combined result of an elevation of $\beta$-hydroxybutyrate concentrations from $194 \pm 136$ to $684 \pm 97 \mu \mathrm{mol} / 1(p<0.005)$ and of acetoacetate levels from $127 \pm 30$ to $288 \pm$ $31 \mu \mathrm{mol} / 1(p<0.02)$. Glucagon replacement resulted in significantly higher acetoacetate concentrations $(p<$ 0.05 ), and in lower $\beta$-hydroxybutyrate/acetoacetate concentration ratios $(2.5 \pm 0.3, p<0.05)$ at $150 \mathrm{~min}$ than during the protocol of glucagon deficiency. The increase in total ketone body concentrations arose from an increase in production from $6.7 \pm 0.9$ to $14.0 \pm 1.9$ $\mu \mathrm{mol} \mathrm{kg} \mathrm{kg}^{-1} \cdot \min ^{-1}(p<0.005)$. The pattern of total ketone body utilization again followed the production rate with a slight delay, causing an increase in total ketone body concentrations. The metabolic clearance rate of total ketone bodies declined during the infusion period by $26 \%(p<0.01)$. The change of production and metabolic clearance of ketone bodies from control rates were not significantly different from the protocol of somatostatin infusion alone (Table 1).

\section{Effect of Hyperglycaemia During Somatostatin Infusion on Ketone Body Kinetics (Fig. 3)}

To examine whether the elevation of blood glucose associated with glucagon infusion influenced the result of ketone body kinetics and lipolysis, glucose was infused into six subjects during somatostatin infusion (protocol 4) to mimic the hyperglycaemia of the glucagon protocol. Total ketone body production rates increased similarly as during somatostatin infusion alone (from $7.1 \pm$ 1.2 to $\left.12.6 \pm 1.2 \mu \mathrm{mol} \cdot \mathrm{kg}^{-1} \cdot \mathrm{min}^{-1}, p<0.01\right)$. Due to the imbalance between ketone body production and utilization, ketone body concentrations rose more than twofold mainly on account of increased $\beta$-hydroxybutyrate concentrations. NEFA and glycerol concentrations increased similarly as during somatostatin alone, indicating that hyperglycaemia during insulin deficiency did not alter lipolysis.

\section{Effect of Glucagon at 2 and $4 \mathrm{ng} \cdot \mathrm{kg}^{-1} \cdot \mathrm{min}^{-1}$ During Insulin Replacement $\left(150 \mu \mathrm{U} \cdot \mathrm{kg}^{-1} \cdot \mathrm{min}^{-1}\right)$ on Ketone Body Kinetics}

Insulin replacement without glucagon (protocol 5) resulted in a slight over-replacement of basal insulin levels in the peripheral circulation (11 \pm 2 at 150 min versus $8.1 \pm 2.1 \mathrm{mU} / 1$ during the control period, $n=6$ ). Glucagon concentrations were lowered during somatostatin infusion by $50 \pm 14 \%(p<0.01)$. Total ketone body production declined transiently from a mean control rate of $5.6 \pm 0.8$ to $3.4 \pm 0.5 \mu \mathrm{mol} \cdot \mathrm{kg}^{-1} \cdot \mathrm{min}^{-1}$ at $90 \mathrm{~min}(p<0.01)$. Due to a delayed fall of ketone body utilization, total ketone body concentrations were lowered by $41 \pm 9 \%$ at $90 \mathrm{~min}$. At the end of the infusions, ketone body kinetics were not significantly different from saline controls (Table 1).

Figure 4 shows the effect of insulin and glucagon replacement at $2 \mathrm{ng} \cdot \mathrm{kg}^{-1} \cdot \min ^{-1}$ (protocol 6) on ketone body kinetics. Glucagon levels were raised to $320 \mathrm{pg} / \mathrm{ml}$ between 105 and $150 \mathrm{~min}$, representing a mean 2.5 -fold elevation of basal concentrations. Insulin levels were again slightly elevated during insulin infusion. Inspite of the addition of glucagon, the rate of total ketone body production declined, to $3.4 \pm 0.4 \mu \mathrm{mol} \cdot \mathrm{kg}^{-1}$. $\min ^{-1}$ ( $45 \%$ of control rate at $\left.150 \mathrm{~min}, p<0.01\right)$. Total 
ketone body utilization followed the production with a slight delay, this imbalance resulting in a gradual decrease of total ketone body concentrations by $69 \pm 4 \%$ at $150 \mathrm{~min}(p<0.01)$.

The glucagon infusions at $4 \mathrm{ng} \cdot \mathrm{kg}^{-1} \cdot \mathrm{min}^{-1}$ (protocol 7) resulted in an increase in plasma glucagon levels to $780 \pm 145 \mathrm{pg} / \mathrm{ml}(n=6)$ at $150 \mathrm{~min}$. These concentrations were twice the levels achieved during the $2 \mathrm{ng} \cdot \mathrm{kg}^{-1} \cdot \mathrm{min}^{-1}$ infusion. Insulin concentrations again increased slightly from $8.2 \pm 1.6$ to $12.7 \pm$ $0.8 \mathrm{mU} / 1$; the insulin levels were similar to the two previous protocols. Total ketone body production decreased to $2.8 \pm 0.5 \mu \mathrm{mol} \cdot \mathrm{kg}^{-1} \cdot \min ^{-1}$ at $90 \min (p$ $<0.05$ ), despite hyperglucagonaemia and remained lowered throughout the study. The fall during the infusion (Table 1) was similar to that found during the $2 \mathrm{ng}$ $\cdot \mathrm{kg}^{-1} \cdot \mathrm{min}^{-1}$ infusion. Total ketone body concentrations decreased significantly to $141 \pm 52 \mu \mathrm{mol} / \mathrm{l}$; thus, neither glucagon infusion rate raised ketone body levels. The metabolic clearance rate of total ketone bodies increased similarly in all three insulin replacement protocols by 28,46 and $35 \%$, respectively $(p<0.05$ ).

\section{NEFA, Glycerol and Glucose Concentrations (Fig. 5)}

NEFA concentrations were not statistically different during the control periods of all protocols. Infusion of somatostatin resulted in a significant $(p<0.05)$ increase in NEFA levels to $1465 \pm 235 \mu \mathrm{mol} / 1$ at $150 \mathrm{~min}$. Glucagon replacement did not alter the NEFA response to insulin deficiency, since NEFA concentrations increased similarly to $1200 \pm 158 \mu \mathrm{mol} / 1(p<$ $0.025)$. All three insulin replacement protocols resulted in lowering of plasma NEFA (Table 2). While this decrease during insulin replacement alone was transient $(57 \pm 6 \%$ of basal at $90 \mathrm{~min}$ ), it was sustained and similar during both glucagon replacement protocols.

The pattern of the glycerol concentrations (not shown on figure) was similar to that of NEFA. Glycerol levels increased significantly during somatostatin infusion from $128 \pm 23$ to $213 \pm 46 \mu \mathrm{mol} / 1(p<0.02)$ at $150 \mathrm{~min}$, and during somatostatin and glucagon from $111 \pm 21$ to $163 \pm 22 \mu \mathrm{mol} / 1(p<0.005)$. During saline infusion, plasma NEFA and glycerol levels did not change significantly.

Blood glucose levels decreased significantly during somatostatin infusion alone from $4.8 \pm 0.2$ to $3.5 \pm$ $0.1 \mu \mathrm{mol} / 1(p<0.001)$ (Fig. 5 and Table 2). In contrast, glucagon replacement exerted a pronounced hyperglycaemic effect, increasing concentrations to $10.4 \pm$ $0.7 \mathrm{mmol} / 1(p<0.001)$. During insulin replacement, blood glucose declined to $3.1 \pm 0.1 \mathrm{mmol} / 1(p<0.01)$, and the addition of glucagon to insulin raised blood glucose to values only moderately lower than in the protocol without insulin. Doubling the glucagon dose to $4 \mathrm{ng} \cdot \mathrm{kg}^{-1} \cdot \mathrm{min}^{-1}$ resulted in blood glucose concentrations of $9.7 \pm 0.4 \mathrm{mmol} / \mathrm{l}$. The increment of blood glucose over the time period ( $150 \mathrm{~min}$ ) was significantly

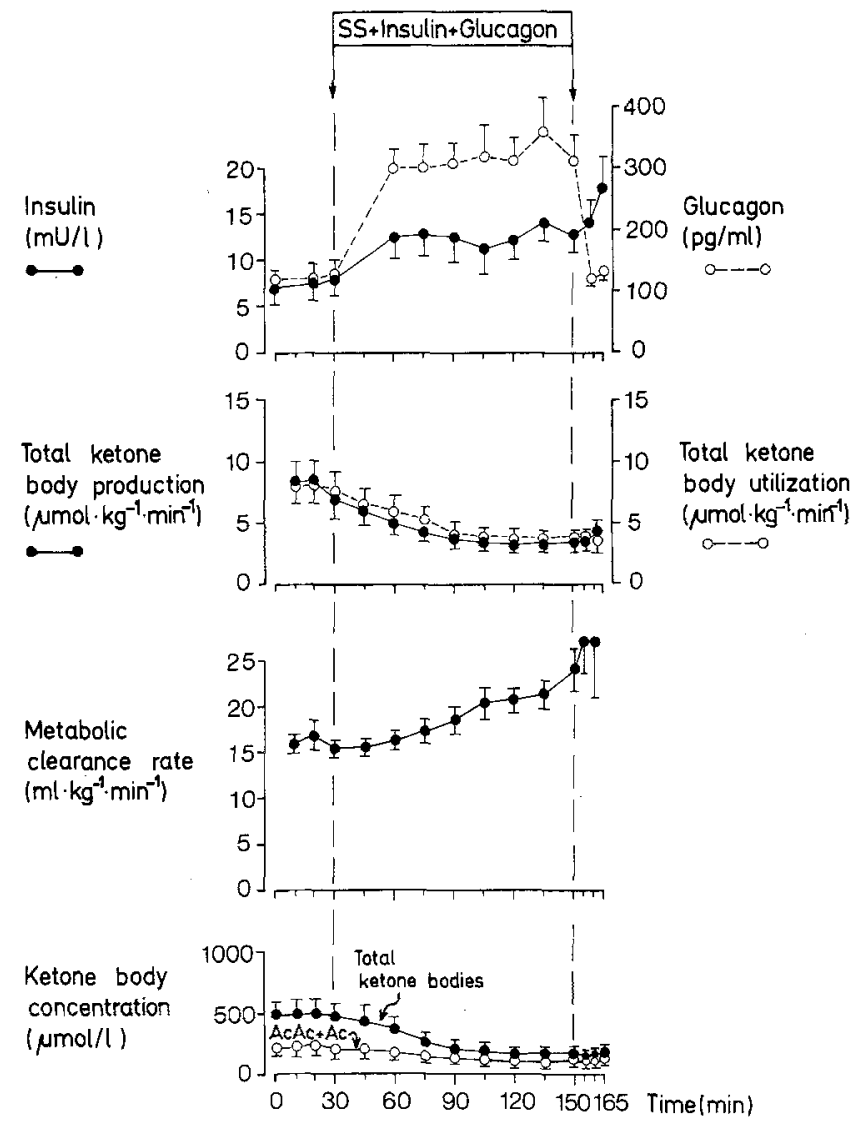

Fig.4. Plasma insulin, glucagon and ketone body kinetics during infusion of somatostatin (SS) with insulin $\left(150 \mu \mathrm{g} \cdot \mathrm{kg}^{-1} \cdot \mathrm{min}^{-1}\right)$ and glucagon $\left(2 \mathrm{ng} \cdot \mathrm{kg}^{-1} \cdot \mathrm{min}^{-1}\right)$ in six subjects. Results expressed as mean $\pm \mathrm{SEM}$

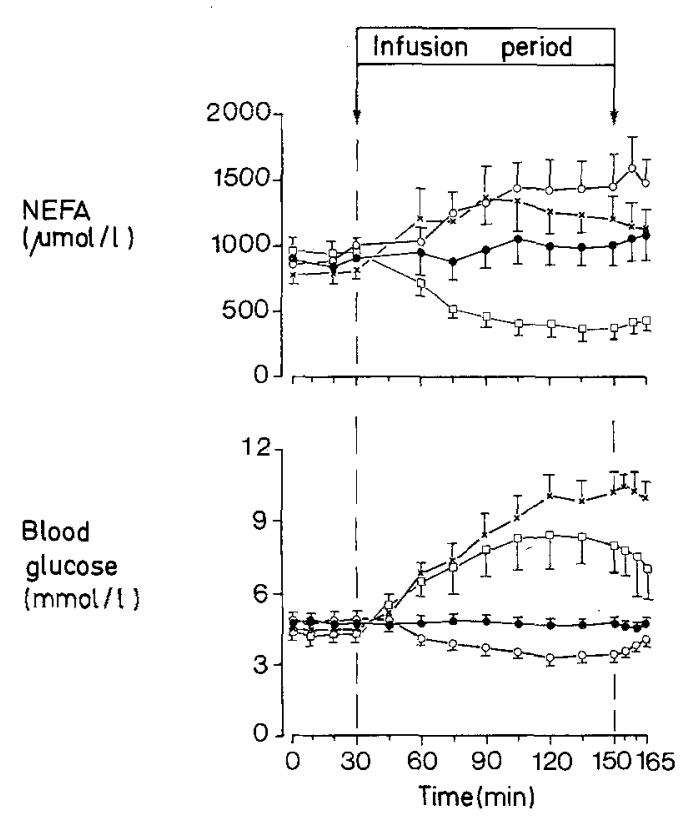

Fig.5. Plasma concentrations of non-esterified fatty acids (NEFA) and blood glucose concentrations during infusion of saline ($n=6$ ), somatostatin ( $\bigcirc-O, n=6)$, somatostatin with glucagon replacement $(\times-\times, n=7)$, and somatostatin with insulin and glucagon replacement at $2 \mathrm{ng} \cdot \mathrm{kg}^{-1} \cdot \min ^{-1}(\square-\square, n=6)$. Results expressed as mean $\pm \mathrm{SEM}$ 
Table 2. Plasma NEFA and blood glucose concentrations at $150 \mathrm{~min}$

\begin{tabular}{|c|c|c|c|}
\hline $\begin{array}{l}\text { Protocol } \\
\text { number }\end{array}$ & $\begin{array}{l}\text { Number } \\
\text { of } \\
\text { patients }\end{array}$ & $\begin{array}{l}\text { NEFA } \\
\text { concentration } \\
(\mu \mathrm{mol} / 1)\end{array}$ & $\begin{array}{l}\text { Glucose } \\
\text { concentration } \\
(\mathrm{mmol} / \mathrm{l})\end{array}$ \\
\hline 1) Saline & 6 & $980 \pm 110$ & $4.7 \pm 0.2$ \\
\hline 2) Somatostatin (SS) & 6 & $1465 \pm 235$ & $3.5 \pm 0.1^{b}$ \\
\hline $\begin{array}{l}\text { 3) } \mathrm{SS}+\text { glucagon } \\
\left(2 \mathrm{ng} \cdot \mathrm{kg}^{-1}\right. \\
\left.\min ^{-1}\right)\end{array}$ & 7 & $1200 \pm 158$ & $10.4 \pm 0.7^{b . c}$ \\
\hline $\begin{array}{l}\text { 4) SS + hypergly- } \\
\text { caemia }\end{array}$ & 6 & $1803 \pm 159^{a}$ & $10.5 \pm 0.3^{b, c}$ \\
\hline $\begin{array}{l}\text { 5) } \mathrm{SS}+\text { insulin } \\
\left(150 \mu \mathrm{U} \cdot \mathrm{kg}^{-1} \text {. }\right. \\
\left.\min ^{-1}\right)\end{array}$ & 6 & $685 \pm 96^{c}$ & $3.1 \pm 0.1^{\mathrm{h}, \mathrm{c}}$ \\
\hline $\begin{array}{l}\text { 6) } \mathrm{SS}+\text { insulin }+ \\
\text { glucagon }(2 \mathrm{ng} \cdot \\
\left.\mathrm{kg}^{-1} \cdot \min ^{-1}\right)\end{array}$ & 6 & $388 \pm 64^{c}$ & $7.9 \pm 0.8^{b . c}$ \\
\hline $\begin{array}{l}\text { 7) } \mathrm{SS}+\text { insulin }+ \\
\text { glucagon }(4 \mathrm{ng} \text {. } \\
\left.\mathrm{kg}^{-1} \cdot \min ^{-1}\right)\end{array}$ & 6 & $374 \pm 39^{c}$ & $9.7 \pm 0.4^{\text {b.c }}$ \\
\hline
\end{tabular}

Results expressed as mean \pm SEM ${ }^{a} p<0.01,{ }^{b} p<0.001$ versus saline, ${ }^{c} p<0.01$ versus somatostatin

higher than during the $2 \mathrm{ng} \cdot \mathrm{kg}^{-1} \cdot \min ^{-1}$ infusion study $\left(512 \pm 18\right.$ versus $359 \pm 53 \mathrm{mmol} \cdot 1^{-1} \cdot \mathrm{min}^{-1}$, $p<0.05)$.

\section{Discussion}

In normal subjects glucagon failed to enhance ketogenesis and lipolysis either during acute insulin deficiency or during maintained insulin levels. The failure of physiological glucagon concentrations to enhance ketone body production in man was unexpected, since stimulatory effects of glucagon on ketogenesis have been demonstrated in animals, such as fasting dogs [21] and rats [2]. Although ketogenic effects of glucagon have never been demonstrated in normal man, elevation of ketone body levels by glucagon has been reported in diabetic patients after insulin withdrawal [3-5]. Glucagon deficiency following pancreatectomy in man resulted in delayed development of ketosis after insulin withdrawal [22]. However, these results were not confirmed in a later study [23].

It is conceivable that under certain conditions, e.g. prolonged insulin deficiency in diabetic patients, glucagon could exert ketogenic effects. However, the present study indicates that during acute insulin deficiency, elevated physiological glucagon levels did not accelerate the development of ketosis, although enhanced lipolysis provided increased substrate levels for ketogenesis. We also demonstrated that hyperglucagonaemia was unable to stimulate ketone body production when NEFA supplied to the liver were limited by near-basal maintained insulin levels. The failure could not be ex- plained by inadequate replacement of intraportal levels by the peripheral infusion, since a portal-peripheral glucagon gradient of 1.3 has been reported [24], and since a hyperglycaemic response of glucagon was preserved.

The observed lowering of $\beta$-hydroxybutyrate/acetoacetate concentration ratios by glucagon extends to man our previous observations in dogs [21] that glucagon lowers this ratio in the liver, suggesting an effect on the intrahepatic redox state [25].

The hyperglycaemia studies indicate that elevation of blood glucose concentrations during insulin deficiency does not diminish lipolysis and ketogenesis. These results are in contrast to those of a previous study in dogs with maintained insulin levels [26]. Our findings provide indirect evidence that hyperglycaemia associated with glucagon infusion does not attenuate ketogenesis or lipolysis.

The present results confirm previous observations of the powerful effect of small changes in insulin concentrations on NEFA levels [27] and thus ketogenesis [1]. The slight over-replacement of insulin was the most likely reason for decreased NEFA and ketone body levels. In addition to the effect on NEFA, a direct hepatic ketogenic effect of insulin may also play a role [28]. Insulin appears to exert a dual effect on ketone body levels, since it not only diminished production but also enhanced the metabolic clearance rate of ketone bodies. These findings agree with previous observations in dogs [29]. Alternatively, the increase in the metabolic clearance rate may be due, at least in part, to a lowering of ketone body concentrations [30].

The finding that glucagon raised blood glucose levels but not ketone body production suggests that there is a marked difference in the relative potency of insulin and glucagon to affect glycogenolysis and ketogenesis, i.e. that ketogenesis is markedly sensitive to insulin but comparatively insensitive to glucagon.

Acknowledgements. This work was supported by the Swiss National Science Foundation, grant No.3.849.77. Appreciation is expressed to Mrs. E. Jaeggi and R. Meyer for their technical assistance and to Mrs. A. Wittker for typing and secretarial assistance.

\section{References}

1. McGarry JD, Foster DW (1980) Regulation of hepatic fatty acid oxidation and ketone body production. Ann Rev Biochem 49: 395-420

2. McGarry JD, Wright PH, Foster DW (1975) Hormonal control of ketogenesis. Rapid activation of hepatic ketogenic capacity in fed rats by anti-insulin serum and glucagon. J Clin Invest 55: 1202-1209

3. Liljenquist JE, Bombay JD, Lewis $\mathrm{SB}$, Sinclair-Smith BC, Felts PW, Lacy WW, Crofford OB, Liddle GW (1974) Effects of glucagon on lipolysis and ketogenesis in normal and diabetic man. $J$ Clin Invest 53: 190-197

4. Gerich JE, Lorenzi M, Bier DM, Tsalikian E, Schneider V, Karam $\mathrm{JH}$, Forsham PH (1976) Effects of physiologic levels of glucagon and growth hormone on human carbohydrate and lipid metabolism. J Clin Invest 57: 875-884 
5. Schade DS, Eaton RP (1975) Glucagon regulation of plasma ketone body concentration in human diabetes. J Clin Invest 56: 1340-1344

6. Schade DS, Eaton PR (1976) Modulation of fatty acid metabolism by glucagon in man. Diabetes 25:978-983

7. Sonnenberg GE, Keller U (1982) Sampling of arterialized heated hand venous blood as a non-invasive technique for the study of ketone body kinetics in man. Metabolism 31: 1-5

8. Krebs HA, Eggleston LV (1945) Metabolism of acetoacetate in animal tissues. Biochem J 39: 408-419

9. Mayes PA, Felts JM (1967) Determination of ${ }^{14} \mathrm{C}$-labelled ketone bodies by liquid scintillation counting. Biochem J 102: 230-235

10. Williamson DH, Mellanby J, Krebs HA (1962) Enzymatic determination of D- $\beta$-hydroxybutyric acid and acetoacetate acid in blood. Biochem J 82: 90-96

11. Young DAB, Renold AE (1966) A fluorimetric procedure for the determination of ketone bodies in very small quantities of blood. Clin Chim Acta 13: 791-793

12. Chernick SS (1969) Determination of glycerol in acyl glycerols. Methods Enzymol 14: 627-630

13. Schmidt FH (1961) Die enzymatische Bestimmung von Glucose und Fructose nebeneinander. Klin Wochenschr 39: 1244-1247

14. Van Stekelenburg GJ, DeBruyn JW (1970) A simple gas chromatographic determination of acetone and $\beta$-ketobutyric acid in blood serum by means of head space gas sampling. Clin Chim Acta 28:233-237

15. Ho RJ (1970) Radiochemical assay of long-chain fatty acids using ${ }^{63} \mathrm{Ni}$ as tracer. Anal Biochem 36: 105-113

16. Wide L, Porath J (1966) Radioimmunoassay of proteins with use of Sephadex-coupled antibodies. Biochim Biophys Acta 130: 257-262

17. Aguilar-Parada E, Eisentraut AM, Unger RH (1969) Pancreatic glucagon secretion in normal and diabetic subjects. Am J Med Sci 257: 415-419

18. Wall JS, Steele R, De Bodo RC, Altszuler N (1957) Effect of insulin on utilization and production of circulating glucose. Am J Physiol 189: 43-50

19. Keller U, Sonnenberg GE, Stauffacher W (1981) Validation of a tracer technique to determine nonsteady-state ketone body turnover rates in man. Am J Physiol 240 (3): E253-E262

20. Miles JM, Rizza RA, Haymond MW, Gerich JE (1980) Effects of acute insulin deficiency on glucose and ketone body turnover in man. Diabetes 29: 926-930
21. Keller U, Shulman G (1979) Effect of glucagon on hepatic fatty acid oxidation and ketogenesis in conscious dogs. Am J Physiol 237 (2): E121-E129

22. Barnes AJ, Bloom SR, Alberti KGMM, Path MCR, Smythe P, Alford FP, Crisholm DJ (1977) Ketoacidosis in pancreatectomized man. New Engl J Med 296: 1250-1253

23. Del Prato S, Nosadini R, Riva F, Fedele D, Devidé A, Tiengo A (1980) Glucagon levels and ketogenesis in human diabetes following total or partial pancreatectomy and severe chronic pancreatitis. Acta Diabetol Lat 17: 111-118

24. Felig P, Gusberg R, Hendler R, Gump F, Kinney T (1974) Concentrations of glucagon and the insulin: glucagon ratio in the portal and peripheral circulation. Proc Soc Exp Biol Med 147: 88-90

25. Williamson DH, Lund P, Krebs HA (1967) The redox state of free nicotinamide-adenine dinucleotide in the cytoplasm and mitochondria of rat liver. Biochem J 103: 514-527

26. Shulman GI Williams PE, Liljenquist JE, Lacy WW, Keller U, Cherrington AD (1980) Effect of hyperglycaemia independent of changes in insulin or glucagon on lipolysis in the conscious dog. Metabolism 29:317-320

27. Zierler KL, Rabinowitz D (1964) Effects of very small concentrations of insulin on forearm metabolism. Persistence of its action on potassium and free fatty acids without its effect on glucose. $J$ Clin Invest 43: 950-962

28. Bieberdorf FA, Chernick SC, Scow RO (1970) Effect of insulin and acute diabetes on plasma FFA and ketone bodies in sheep. Am J Physiol 205: 1685-1693

29. Balasse EO, Havel RJ (1971) Evidence for an effect of insulin on the peripheral utilization of ketone bodies in dogs. J Clin Invest 50: 801-813

30. Balasse EO (1979) Kinetics of ketone body metabolism in fasting humans. Metabolism 28: 41-50

Received: 14 April 1981

and in revised form: 6 April 1982

Dr. Ulrich Keller

Medizinische Abteilung

Universitäts-Krankenhaus

CH-4031 Basel, Switzerland 